\title{
Design, Construction and Implementation of Low Cost Photovoltaic Water Pumping System for Agricultural Irrigation
}

\author{
A. GUNDOGDU and B. GURE
}

\begin{abstract}
In this study, design, manufacturing and installation of a new agricultural irrigation system with a $2.2 \mathrm{~kW}$ photovoltaic (PV) panel, which has a lower volume and lower cost in terms of size and cost, was carried out within the boundaries of Batman province that has a long sunshine duration. Through making winding and connection changes on a $380 \mathrm{v}$-star connected asynchronous submersible motor with $\mathbf{2 . 2}$ kW power, which operates compatibly with HSPL/H2200H model inverter, the HSPL/H2200L model inverter was brought in compliance with the delta having $220 \mathrm{v}$ between its phases and having output voltage. Dimension analysis of a photovoltaic system that was independent of the grid and where this new voltage level would be obtained was performed and the operation of rewinding the motor and changing the connection shape was explained. The real-time current, voltage and power data obtained after the installation are presented in tables and graphs. The advantages of this low-cost new irrigation system over the existing irrigation systems with similar power are explained in detail through the size and cost analyses.
\end{abstract}

Index Terms-Photovoltaic Energy, PV System, Agricultural Irrigation.

\section{INTRODUCTION}

$\mathrm{B}$ OTH THE INEFFICIENT use of conventional energy sources and the rapid depletion of them have led mankind to use clean and non-depleted renewable energy sources. Considering the high cost of the energy generated from conventional energy sources and their harmful effects on the environment, solar energy, which is used widely in heating and electricity generation, has an important place among renewable energy sources.

The use of renewable energy sources has increased seriously due to their environmental and economic benefits, being abundant and widespread, rapid improvements provided for

AHMET GÜNDOĞDU, is with Department of Electrical Engineering University of Batman University, Batman, Turkey, (e-mail: ahmet.gundogdu@batman.edu.tr).

iD https://orcid.org/0000-0001-7240-204X

BAYRAM GÜRE, is with Gure Engineering, Batman, Turkey, (e-mail: editor@bajece.com).

(iD https://orcid.org/0000-0003-1653-6451

Manuscript received December 6, 2018; accepted January 30, 2019. DOI: $\underline{10.17694 / \text { bajece. } 492804}$ them to compete with other manufacturing technologies, developing technologies and thereby decreasing costs, concerns about the environmental impact of fossil fuels, major and significant incentives given in many countries of the world ( $\$ 120$ billion in 2015) [1].

According to the IEA [1] and EIA [2], by 2040, worldwide hydropower and other renewable energy sources consumption is expected to increase by $3.2 \%$ and $2.9 \%$, respectively. It is forecasted that the largest installed power contribution to the increase in renewable resources will come from wind energy with $863 \mathrm{GW}$ and solar energy (PV) with $815 \mathrm{GW}$. The share of renewable energy sources in the electricity generation is estimated to reach from $22.6 \%$ in 2014 to $26.0 \%$ in 2020 and to $29.0 \%$ in 2040 [1].

It is seen that there have been significant increases in the applications of generating electric energy from solar energy with the help of photovoltaic panels in recent years. It has reached important levels in the European Union (87 GW), especially in Germany and Italy [4]. China (28 GW), Japan (23 GW) and the United States (19 GW) are among the countries that are making progress in this area [3].

Looking at the global greenhouse gas emissions, it is seen that the largest share belongs to the Energy Sector with $34.6 \%$ and $25 \%$ of this is due to the oil, natural gas, and coal used in electricity and heat production [5, 6]. Most CO2-emitting countries are listed as China, the United States, the EU, India, Russia, and Japan. Turkey ranks $17^{\text {th }}$ in this list [7].

According to the previous research, it is stated that $26 \%$ of the energy needs on a global scale can be met from solar energy by 2040 and serious employment areas will be provided in this sector. It is known that in our country, which is largely based on agriculture, electrical energy is consumed seriously in agricultural irrigation applications.

Our country has 78 million hectares of land and about 28 million hectares of this is used as agricultural land. Irrigable agricultural land is about 8.5 million hectares [8]. In this regard, solar energy should be used for agricultural irrigation purposes. In our country, which has high sunshine duration, photovoltaic systems that produce electricity primarily for agricultural purposes should be installed in rural areas where there is no electrical energy or where the energy transmission lines do not reach. With the establishment of these systems, high energy and production costs in grid-connected irrigation systems can be reduced. Although the first installation cost of these systems is high and its efficiency depends on instant 
weather conditions [9], it is seen as an economic solution in the long term.

Some recent studies on agricultural irrigation with photovoltaic solar energy and the results of these studies are summarized below.

Yeşilata and Aktacir focused on the design of the solarpowered water pump systems and they created graphs to facilitate the selection of the elements forming the system [10].

By taking advantage of variable-speed centrifugal pumps, opportunities to increase the efficiency of deep well pumps operating with photovoltaic effect were investigated by Fiaschi et al., and comparisons were made taking into consideration the photovoltaic system which produces $30 \mathrm{~m}^{2}$ and about $3 \mathrm{~kW}$ power that can draw water from $100 \mathrm{~m}$ deep wells [11].

Kavlak and Güngör stated that it would be more convenient to use solar-powered water pumps instead of diesel engine pumping system operating with diesel fuel [12].

Purohit and Kandpal investigated the renewable energies that could be used in water pumping systems in India and examined the systems comprised of pumps operating with photovoltaic system, biogas and wind propellers [13].

A converter for a three phase $12 / 8$ pole reluctance motor with $300 \mathrm{~W}$ power was designed by Dursun and Saygın. This driver was used to operate the pump in the irrigation system [14].

A mathematical model for the solar powered agricultural irrigation system was created by Glasnovic and Margeta (2007). In Croatia, analyses were carried out taking into account radiation, climate, irrigation methods and planted plants for 30 regions. As a result of these analyses, it was concluded that solar energy could be used in irrigation, but it was also concluded that because the sunshine duration was varied, it had a negative effect on agricultural irrigation [15].

Ramos and Ramos examined the usability of the solar energy systems in the methods of water drawing from wells, especially in developing countries such as Africa, North Asia and Latin America. They indicated that it had many areas of usage. And, they calculated an initial investment cost and the water cost associated with this cost [16].

In another research, a study was carried out on both lighting and irrigation with a $610 \mathrm{~W}$ photovoltaic system, which was independent from the grid, by Kaldellis et al. [17].

In Guatemala, a Central American country, Granich and Elmore investigated whether the water transported from the deep water well to a high tank with a pump system and accumulated in this tank can meet the water requirement at home. It was concluded that the generated electrical energy was not sufficient for the pumping system. It was also concluded that this system was not economical, but it could be economical when compared with the installation of the grid line in the areas where there was no electrical grid system [18].

By Dursun and his colleagues, the performance analyses of the photovoltaic, wind turbine and fuel cell power generation systems were made for the Aegean region [19].

Chen et al. explained wind and solar energy generation systems, which are among the renewable energy sources, and made cost, benefit, and risk analyses for the generation of solar wind hybrid energy [20].
Mokeddem et al. designed a photovoltaic system for use in different climate conditions and radiation values and they conducted an efficiency analysis of the DC pump used in that system [21].

It was emphasized by Belgacem that it would be economical to make irrigation in rural areas in less developed countries with the help of photovoltaic energy. It was proved that solar energy can be used for pumping water, especially in Tunisian conditions having 3000 hour yearly sunshine duration and 6 $\mathrm{kWh} / \mathrm{m} 2$ daily values [22].

In order to evaluate solar energy potential in the South East Anatolia region, Yusufoğlu made agricultural irrigation with a photovoltaic system using a DC pump [23].

Gençoğlu carried out the design of a solar powered photovoltaic water pumping system controlled by PLC, which was independent of the grid [24].

Gündoğdu analyzed the effects of shading affecting the system performance adversely in terms of current, voltage, and power in a photovoltaic system having $5 \times 5$ matrix array. The effects of shading, which emerges based on atmospheric and environmental conditions, on both panel efficiency and overall system efficiency were studied. The simulation model of this system consisting of 25 panels and having a maximum power point of $2.1 \mathrm{~kW}$ was created in the MATLAB/Simulink environment [25].

Especially in mountainous and remote agricultural lands where there is no grid electricity, diesel generators are generally used for irrigation. With the electrical energy obtained from these generators, submersible water motor are operated and irrigation is performed. Because of the high fuel costs, this system is not seen as very useful. Given this situation, the use of photovoltaic panels in agricultural irrigation in the short and long term is inevitable. In accordance with this aim, design, manufacturing and field application of a low-cost photovoltaic water pumping system for agricultural irrigation was carried out in this study.

\section{DESIGN OF PHOTOVOLTAIC WATER IRRIGATION SYSTEM}

PV systems are a good solution for irrigation in remote agricultural areas where electrical energy is not available. For this purpose, either fixed or portable systems have been designed. Although fixed systems are relatively cheaper than portable systems, they are also at risk of theft due to the fact that they are far away from the residential areas. In this respect, portable PV systems are more suitable for use.

Up to a certain power, photovoltaic systems can be designed as having storage. However, this type of design is not preferred because of the high cost of storage elements. When the sun is insufficient or especially during the night, systems without storage do not work. However, in systems without storage that we want it to operate during the night, the pool or water tanks that provide the storage of water is used. The system designed in this study is a grid independent system that is carried out without the use of energy storage elements. The general principal scheme of this irrigation system is given in Figure 1. 


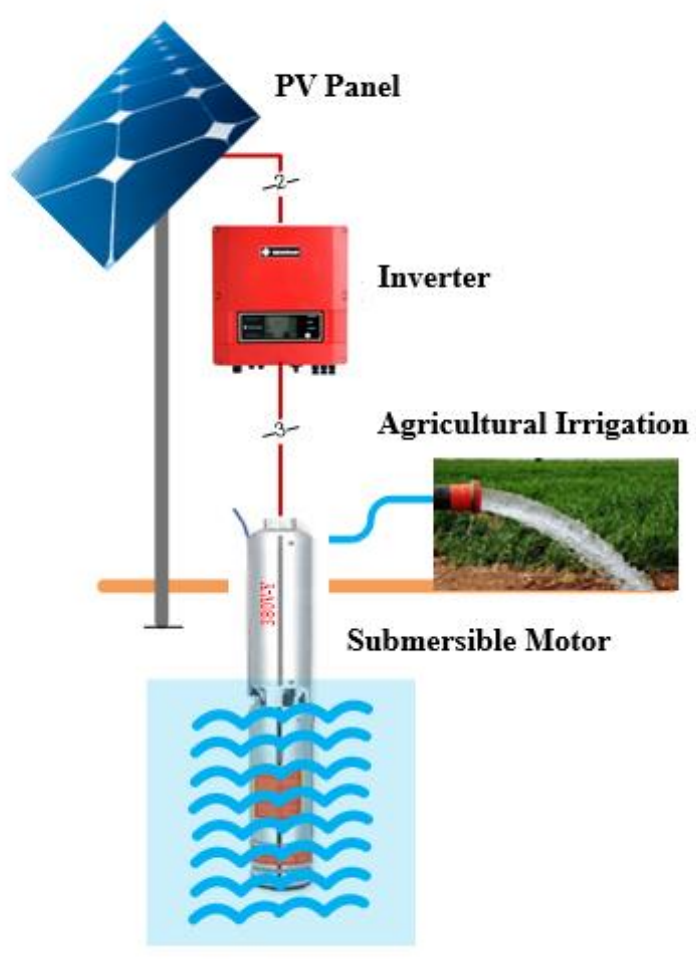

Figure 1. The principal scheme of the photovoltaic agricultural irrigation system

\section{A. Selection of Submersible Pump}

In the designed system, there is a 50-ton water tank where the water drawn from the ground will be stored, and this tank is intended to be filled in approximately 6 hours. The well is $65 \mathrm{~m}$ deep and there are $200 \mathrm{~m}$ distance between the well and the water tank. The submersible motor will be taken down to $50 \mathrm{~m}$ below the ground. In addition, the height difference between the exit point of the well and the tank (elevation difference) is $0 \mathrm{~m}$. In order to fill the tank within 6 hours, $50 / 6=8.3 \mathrm{~m}^{3} / \mathrm{h}$ water must be supplied from the well. The closest value to the water amount of $8.3 \mathrm{~m}^{3} / \mathrm{h}$ that should be supplied per hour is $9 \mathrm{~m}^{3} / \mathrm{h}$. Taking into account this data, the outer diameter of the polyethylene hose to be laid on the soil ground along a distance of $200 \mathrm{~m}$ was found to be $63 \mathrm{~mm}$ with the help of Table I.

TABLE I

PLASTIC PIPE SELECTION TABLE

\begin{tabular}{|c|c|c|c|c|c|c|}
\hline \multicolumn{2}{|l|}{ Outer Diam. of Plastic Pipe } & 25 & 40 & 50 & 63 \\
\hline \multicolumn{2}{|l|}{ Nom. Diam. of Plastic Pipe } & 20 & 32 & 40 & 50 \\
\hline \multicolumn{2}{|l|}{ Metal Water Pipes } & $3 / 4 "$ & 1 1"1/4 & 1 1"1/2 & $2 "$ \\
\hline $\mathrm{m}^{3} / \mathrm{h}$ & $1 / \mathrm{min}$ & $1 / \mathrm{s}$ & \multicolumn{5}{|c|}{ Friction loss per $100 \mathrm{~m}$} \\
\hline 2.1 & 35 & 0.6 & 29.8 & 2.8 & 0.9 & 0.3 \\
\hline$\downarrow$ & $\downarrow$ & $\downarrow$ & $\downarrow$ & $\downarrow$ & $\downarrow$ & $\downarrow$ \\
\hline 9 & 150 & 2.5 & & 63 & 24.5 & 4.7 \\
\hline
\end{tabular}

If the friction loss in the polyethylene hose, which will be used in 200 meter horizontal distance, is $4.7 \mathrm{~m}$ for every 100 $\mathrm{m}$ distance, it is calculated as $2 \times 4.7=9.4 \mathrm{~m}$ for $200 \mathrm{~m}$. In this case, the depth to which the submersible motor needs to be taken down is calculated as $50+9.4=59.4 \mathrm{~m}$. Depending on the water amount of $8.3 \mathrm{~m}^{3} / \mathrm{h}$ per hour and the depth of 59.4 $\mathrm{m}$, to which the submersible motor needs to be taken down, and with the help of Table II, the power of the submersible motor was determined as $3 \mathrm{Hp}$ and pump type was determined as $\mathrm{S} 48 / 13$.

TABLE II

PUMP SELECTION TABLE

\begin{tabular}{|c|c|c|c|c|c|c|c|c|c|c|c|c|c|c|}
\hline \multirow{3}{*}{$\begin{array}{c}\text { Pump } \\
\text { Type }\end{array}$} & \multirow{3}{*}{ Нр } & \multicolumn{10}{|c|}{ Flow Rate } & Outlet & Height & Weight \\
\hline & & $\mathrm{m}^{3} / \mathrm{h}$ & 0 & 4.8 & 5.4 & 6 & 7.2 & 8.4 & 9.6 & 10.8 & 12 & \multirow{2}{*}{ inch } & \multirow{2}{*}{$\mathrm{mm}$} & \multirow{2}{*}{$\mathrm{Kg}$} \\
\hline & & $1 / \mathrm{s}$ & 0 & 1.33 & 1.5 & 1.67 & 2 & 2.33 & 2.67 & 3 & 3.33 & & & \\
\hline S4 8/ 06 & 1.5 & \multirow{6}{*}{ MSS } & 38 & 35 & 34 & 33 & 31 & 28 & 24 & 19 & 14 & \multirow{6}{*}{$2^{\prime \prime}$} & 356 & 3.4 \\
\hline S4 8/ 08 & 2 & & 52 & 47 & 45 & 44 & 41 & 37 & 31 & 25 & 18 & & 418 & 4 \\
\hline S4 8/ 13 & 3 & & 82 & 75 & 73 & 71 & 66 & 59 & 50 & 40 & 30 & & 573 & 5.5 \\
\hline S4 8/ 17 & 4 & & 108 & 98 & 96 & 94 & 87 & 79 & 70 & 58 & 46 & & 697 & 6.6 \\
\hline S4 8/ 23 & 5.5 & & 148 & 134 & 131 & 127 & 118 & 108 & 95 & 79 & 60 & & 959 & 9.4 \\
\hline S4 8/ 32 & 7.5 & & 202 & 182 & 178 & 172 & 160 & 143 & 125 & 105 & 80 & & 1276 & 12 \\
\hline
\end{tabular}




\section{B. Motor and Inverter Selection}

Whether they are fixed or portable, photovoltaic systems have high installation costs in today's conditions. In order to reduce this cost, a different approach was proposed in this study and the validity of this proposal was verified by the conducted studies. With this new approach, a low cost $380 \mathrm{~V}$ starconnected asynchronous submersible motor with $3 \mathrm{Hp}(2.2$ $\mathrm{kW}$ ) power, which was commonly found in the market, was used as a submersible pump motor.

There is no motor operating with phase to phase voltage $220 \mathrm{v}$ in Turkey standards because the voltage between phases is $380 \mathrm{v}$ and $380 \mathrm{v}$ star-connected motor types are widely used. The connection of this $380 \mathrm{v}$ star-connected motor was transformed into a $220 \mathrm{v}$ delta-connection, thus a decrease in the number of photovoltaic panels that would supply this motor was ensured. The decrease in the number of panels also provided an opportunity to realize the whole system at less cost and smaller sizes.

In the selection of inverter, values related to two different inverter models that have two different maximum power point (MPP) values and that are widely used in the market were taken into consideration. The power, voltage and model information for both inverter models are given in Table III.

TABLE III

INVERTER SELECTION TABLE

\begin{tabular}{|c|c|c|c|c|}
\hline $\begin{array}{c}\text { Inverter } \\
\text { Model }\end{array}$ & $\begin{array}{c}\text { Inverter } \\
\text { Power }\end{array}$ & $\begin{array}{c}\text { Inverter } \\
\text { Input Volt. }\end{array}$ & $\begin{array}{c}\text { Inverter } \\
\text { Output Volt. }\end{array}$ & Motor \\
\hline $\begin{array}{c}\text { HSPL/ } \\
\text { H2200H }\end{array}$ & $3 \mathrm{Hp}$ & $400-780 \mathrm{~V}$ & $380 / 400 / 440 \mathrm{~V}$ & Star \\
\hline $\begin{array}{c}\text { HSPL/ } \\
\text { H2200L }\end{array}$ & $3 \mathrm{Hp}$ & $200-450 \mathrm{~V}$ & $220 / 240 \mathrm{~V}$ & Delta \\
\hline
\end{tabular}

According to Table 3, the suitable inverter model for the asynchronous submersible motor which is converted into a $220 \mathrm{v}$ delta-connection is HSPL/H2200L. The input voltage values of both inverters show variance according to both connection shapes of the selected motor. While this value is in the range of $200 \mathrm{v}-450 \mathrm{v}$ in the HSPL/H2200L inverter model, it is in the range of $400 \mathrm{v}-780 \mathrm{v}$ in the HSPL/H2200H model.

When determining the number of panels to be used, motor connection shape, operating voltage and inverter input and output voltages given in the table were taken into account. The number of panels that will be used to capture inverter input voltage in HSPL/H2200H is greater than the number of panels that will be used in HSPL/H2200L.

With the HSPL/H2200H model inverter, the 380v starconnected motor can be easily operated and also the $220 \mathrm{v}$ delta motor can be easily operated with the HSPL/H2200L model inverter. HSPL/H2200L model inverter with input voltage $200 v-450 v$ DC and output voltage $220 / 240$ v AC was preferred in this designed new photovoltaic system.

\section{Calculation of the Photovoltaic Panel Power}

The selection and sizing of photovoltaic solar panels was determined according to the selection of asynchronous submersible motor and inverter to be used in the pump system.
The number of panels and the dimension analysis to be used in the photovoltaic system where we will obtain the voltages required for the star and delta connected states of $3 \mathrm{Hp}$ asynchronous submersible motor are given below separately. For use in the system, catalog values of some of the OSP coded polycrystalline panels are given in Table IV. Among these, the OSP250 model panel with the value of $250 \mathrm{Wp}$ was preferred.

TABLE IV PHOTOVOLTAIC PANEL SELECTION TABLE

\begin{tabular}{|r|c|c|c|}
\hline & OSP150 & OSP250 & OSP260 \\
\hline $\mathrm{P}_{\max }(\mathrm{W})$ & 150 & 250 & 260 \\
\hline $\mathrm{V}_{\mathrm{oc}}(\mathrm{V})$ & 22,3 & 37,8 & 38 \\
\hline $\mathrm{V}_{\mathrm{mpp}}(\mathrm{V})$ & 18,6 & 30,5 & 30,8 \\
\hline $\mathrm{I}_{\mathrm{sc}}(\mathrm{A})$ & 8,5 & 8,7 & 8,96 \\
\hline $\mathrm{I}_{\mathrm{mpp}}(\mathrm{A})$ & 8,1 & 8,2 & 8,45 \\
\hline $\mathrm{n}(\%)$ & 15,4 & 15,7 & 16 \\
\hline$(\mathrm{Kg})$ & 10 & 18 & 18 \\
\hline $\mathrm{piece}$ & 36 & 60 & 60 \\
\hline $\mathrm{E} / \mathrm{B} / \mathrm{K}$ & $994 * 1014 * 40$ & $1640 * 992 * 40$ & $1640 * 992 * 40$ \\
\hline$(\mathrm{STC})$ & \multicolumn{3}{|c|}{$\left.\mathrm{E}=1000 \mathrm{w} / \mathrm{m}^{2}, \mathrm{AM}=1,5, \mathrm{~T}\right)=25^{\circ} \mathrm{C}$} \\
\hline
\end{tabular}

In case of using the $380 \mathrm{v}$ star-connected submersible motor, determination of the number of panels required and calculation of the total voltage were made as follows. The voltage between phases that the motor needs according to the connection shape is $380 \mathrm{v}$. The output voltage of $\mathrm{HSPL} / \mathrm{H} 2200 \mathrm{H}$ inverter model given in Table III is $380 \mathrm{v}$ and it is suitable for the motor. However, the DC bus input voltage range of this inverter is $400 \mathrm{v}-780 \mathrm{v}$ and its MPP voltage is greater than $500 \mathrm{~V}$. Minimum number of panels that will provide this input voltage to the inverter is;

Min. Panel Number (Star) $=\frac{500}{30.5} \cong 16$

Depending on the width and height catalog values of 1640x992 mm, the area of a panel is calculated as follows:

Area of a Panel $=1.64 \times 0.992=1.626 \mathrm{~m}^{2}$

The total area of 16 panels is found as $1.626 \times 16=26 \mathrm{~m}^{2}$. The arrangement of these 16 pieces OSP250 model panels connected in series is given in Figure 2. Taking into account the unit price of the used photovoltaic panel as 155 \$ including VAT as of November 2018, the total panel cost is calculated as $16 \times 155 \$=2480 \$$.

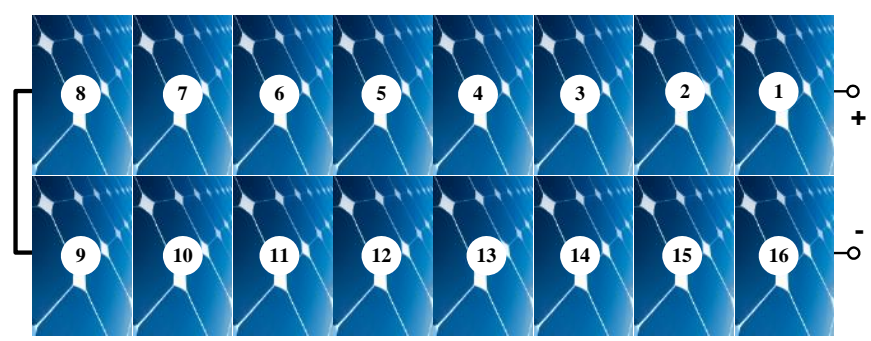

Figure 2. Arrangement of 16 photovoltaic panels 
In case of use of $220 \mathrm{v}$ star-connected submersible motor, determination of the needed number of panels and calculation of the total voltage was done as follows. The voltage between phases that the motor needs according to the connection shape is $220 \mathrm{v}$. The output voltage of $\mathrm{HSPL} / \mathrm{H} 2200 \mathrm{H}$ inverter model given in Table III is $220 \mathrm{~V}$ and this is suitable for the motor. However, the DC bus input voltage range of this inverter is $200 \mathrm{v}-450 \mathrm{v}$ and its MPP voltage is greater than $300 \mathrm{~V}$. Minimum number of panels that will provide this input voltage to the inverter is;

Min. Panel Number (Delta) $=\frac{300}{30.5} \cong 10$

It should be needed that the total open circuit voltage obtained by serial connection of the panels i) do not exceed the inverter open circuit voltage and ii) it is within the range of $200 \mathrm{v}-450 \mathrm{v}$ which is the inverter input voltage of MPP voltage. For the photovoltaic system to operate more efficiently, the system installation can be realized up to 1.4 times of the installed power needed in practice. In this case, the total panel power is the following.

Total Panel Power (Delta) $=2200 \mathrm{Wx} 1.4=3080 \mathrm{~W}$

The number of panels that is needed to be used depending on this new modified power value is:

Total Panel number (Delta) $=\frac{3080}{250} \cong 12$ adet

In the condition in which 12 panels with $250 \mathrm{Wp}$ value are connected in serial,

$$
\text { Open Circuit Voltage }=12 \times 37.8 \mathrm{~V}=453.6 \mathrm{~V}
$$

MPP Voltage $=12 \times 30.5 \mathrm{~V}=366 \mathrm{~V}$

Although the total open circuit voltage is above the $453.6 \mathrm{v} \geq$ $450 \mathrm{v}$ limit, this $0.8 \%$ voltage excess does not constitute a problem in terms of the inverter. In the condition in which the motor is delta-connected, the number of panels to provide the required operating voltage was found as 12 . Since the same panels will be used, the total area to be occupied by 12 panels is calculated as $1.626 \times 12=20 \mathrm{~m}^{2}$. The arrangement of these 12 piece OSP250 model panels connected in series is given in Figure 3. Taking into account the unit price of the used photovoltaic panel as 155 \$ including VAT as of November 2018 , the total panel cost is calculated as $12 \times 155 \$=1860 \$$.

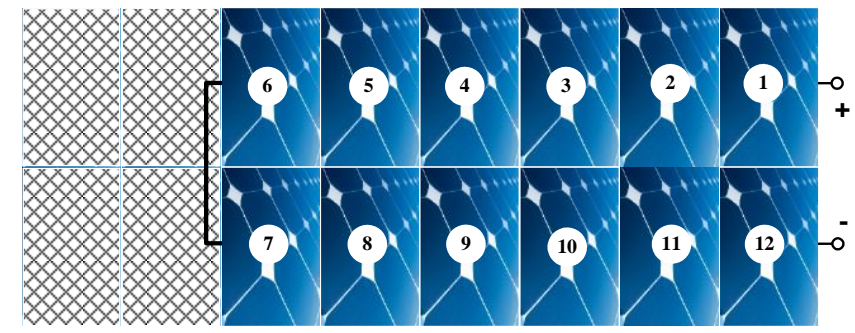

Figure 3. Arrangement of 12 photovoltaic panels
In summary, the results obtained from the above calculations for the star and delta connected states of the asynchronous submersible motor to be used are given below comparatively.

$$
\begin{aligned}
& \text { Panel Num. }(\text { Star })=16>\text { Panel Num. (Delta) }=12 \\
& \text { PanelArea }(\text { Star })=26 \mathrm{~m}^{2}>\text { PanelArea }(\text { Delta })=20 \mathrm{~m}^{2} \\
& \text { Cost }(\text { Star })=13120 \mathrm{TL}>\text { Cost } \text { (Delta) }=9840 \mathrm{TL}
\end{aligned}
$$

As a result of the conversion of the connection shape of the asynchronous submersible motor having 380v star voltage to $220 \mathrm{v}$ delta, a $25 \%$ decrease in total panel number, a $25 \%$ decrease in the physical area where photovoltaic panels would be installed, and a $25 \%$ decrease in total panel cost occurred.

\section{Winding and Connection Change Performed on the Motor}

For steady state and in the conditions in which $380 \mathrm{v}$ star or $220 \mathrm{v}$ delta is connected, the power that the $3 \mathrm{Hp}$ asynchronous submersible motor used in photovoltaic irrigation system will draw from the grid is not change. Although $380 \mathrm{v}$ is applied between the phases of the $380 \mathrm{v}$ star-connected motor, $380 / \sqrt{ } 3$ $=220$ volt voltage falls to each phase winding.

If the connection of the same motor is converted to $220 \mathrm{v}$ delta, then $220 \mathrm{v}$ must be applied as phase to phase voltage. In the delta connection, the phase to phase voltage is equal to the winding voltage of each phase of the motor at the same time.

The asynchronous submersible motor whose general view, winding end diagram and terminal connection are given in Figure 4 has an operating voltage of $380 \mathrm{v}$ star connected as the fabrication. It has been winded as 24 slot and $2 p=2$ pole.
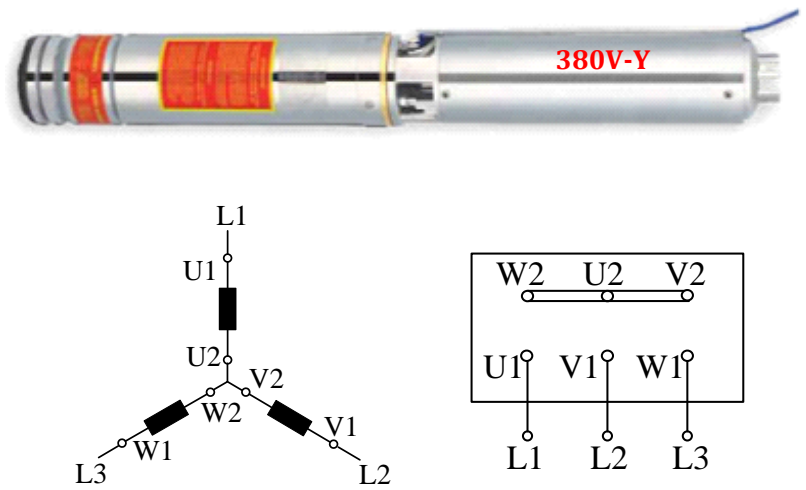

Figure 4. Winding diagram and terminal connection of the 380v star-connected asynchronous submersible motor.

In order to make, it suitable for $220 \mathrm{v}$ delta connection, the current motor windings of this motor, which has 24-slot stator, were removed and re-winded with the 2-pole hand-style winding scheme given in Figure 5. 


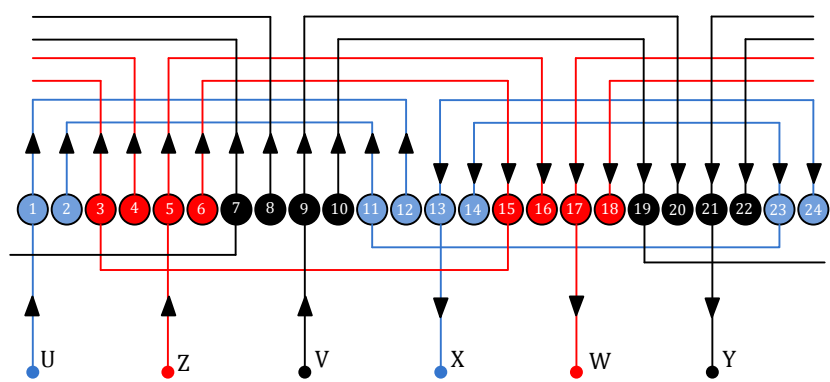

Figure 5. 2-pole Hand Style Winding Scheme $(2 p=2, x=24$, $\mathrm{m}=3$ )

The photos related to the conducted winding is given in Figure 6 . The coils were set in the slots by using $0,2 \pi / 3$ and $4 \pi / 3$ mechanical settlement angles, respectively. After a total of six coils (two coils for each phase) were placed in the slots, a total of six ends were taken out. Three of these ends were phase winding input ends and the other three were phase winding output ends.
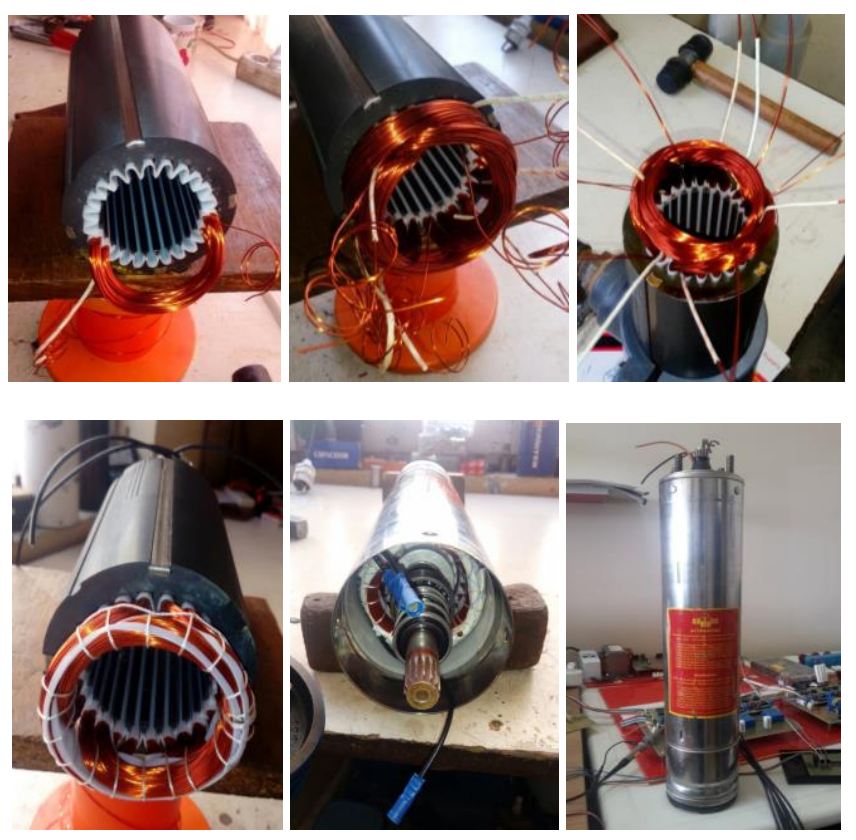

Figure 6. The photos related to motor winding process

After completion of the winding process of the stator, the required varnish, insulation and soldering were made; then, delta was connected to it and it was packaged. Figure 7 shows the winding end diagram belonging to the delta connection of the motor and also shows the terminal connections of it.

Before the packaging, by connecting firstly star and then delta to the motor whose winding process had been completed, the number of current, voltage and cycles were measured in the laboratory environment. The obtained numbers of current, voltage and speed are given in Table $\mathrm{V}$ below.
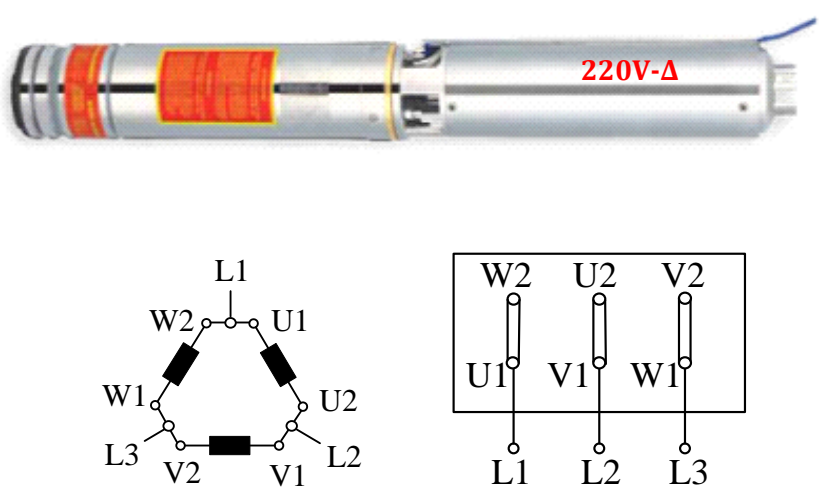

Figure 7. Winding end diagram and terminal connection of the $380 v$ delta-connected asynchronous submersible motor.

TABLE V

CURRENT, VOLTAGE AND SPEED VALUES OF THE MOTOR WHOSE WINDING PROCESS WAS COMPLETED

\begin{tabular}{|r|c|c|}
\hline & $380 \mathrm{v}-\mathrm{star}$ & 220v-delta \\
\hline Line Current (IL) & $3.18 \mathrm{~A}$ & $5.51 \mathrm{~A}$ \\
\hline Phase Current (Ip) & $3.18 \mathrm{~A}$ & $5.51 / \sqrt{3}=3.18 \mathrm{~A}$ \\
\hline Line Voltage $\left(\mathrm{V}_{\mathrm{L}}\right)$ & $380 \mathrm{~V}$ & $220 \mathrm{~V}$ \\
\hline Phase Voltage(V) & $380 / \sqrt{3}=220 \mathrm{~V}$ & $220 \mathrm{~V}$ \\
\hline Ref. Freq. & $50 \mathrm{~Hz}$ & $50 \mathrm{~Hz}$ \\
\hline Speed & $2985 \mathrm{rad} / \mathrm{m}$ & $2991 \mathrm{rad} / \mathrm{m}$ \\
\hline
\end{tabular}

The catalog values of the 3-Hp asynchronous submersible motor used in the designed photovoltaic irrigation system are 3 phases, $50 \mathrm{~Hz}, 2.2 \mathrm{~kW}, 380 \mathrm{v}, 5.6 \mathrm{~A}, 2800 \mathrm{rad} / \mathrm{m}$ and $\operatorname{Cos} \varphi=0.82$.

- In the condition in which $380 \mathrm{v}$-star is connected to motor, the power that the motor will pull from the grid per phase;

$\mathrm{P}_{\text {phase }}=\mathrm{U}_{\mathrm{p}} \times \mathrm{I}_{\mathrm{p}} \times \operatorname{Cos}_{\varphi}$

The total power that the motor will draw from the grid;

$\mathrm{P}_{\mathrm{T}}=\mathrm{P}_{\mathrm{R}}+\mathrm{P}_{\mathrm{S}}+\mathrm{P}_{\mathrm{T}}=3 \times \mathrm{U}_{\mathrm{p}} \times \mathrm{I}_{\mathrm{p}} \times \operatorname{Cos}_{\varphi}$

$\mathrm{I}_{\text {line }}=\mathrm{I}_{\text {phase }}$

$\mathrm{U}_{\text {line }}=\sqrt{3} \mathrm{x} \mathrm{U}_{\text {phase }}$

$\mathrm{U}_{\text {phase }}=\frac{\mathrm{U}_{\text {line }}}{\sqrt{3}}=\frac{380}{\sqrt{3}}=220 \mathrm{~V}$

- In the condition in which $220 \mathrm{v}$-delta is connected to the motor, the power that the motor will draw from the grid per phase;

$P_{\text {phase }}=U_{p} \times I_{p} \times \operatorname{Cos}_{\varphi}$ 
The total power that the motor will draw from the grid;

$\mathrm{P}_{\mathrm{T}}=\mathrm{P}_{\mathrm{R}}+\mathrm{P}_{\mathrm{S}}+\mathrm{P}_{\mathrm{T}}=3 \times \mathrm{U}_{\mathrm{p}} \times \mathrm{I}_{\mathrm{p}} \times \operatorname{Cos}_{\varphi}$

$\mathrm{U}_{\text {line }}=\mathrm{U}_{\text {phase }}=220 \mathrm{~V}$

$\mathrm{I}_{\text {line }}=\sqrt{3} \mathrm{x} \mathrm{I}_{\text {phase }}$

$\mathrm{I}_{\text {phase }}=\frac{\mathbb{1}_{\text {line }}}{\sqrt{3}}$

In the case of both connections, the ratio of the powers drawn by the motor from the grid to each other are shown equation (19), (20).
This result indicates that the power that the motor will draw from the grid is equal in both the star and the delta connection. That is, no change in the motor's power and performance occur when the connection shape of the motor is converted from star to the delta. Related to these both conditions (star and delta connections) in MATLAB/Simulink environment, various simulation studies were carried out on a 3-phase simple R load with a power of $2.2 \mathrm{~kW}$. The current, voltage and power graphs obtained as a result of these studies are given below.

$$
\begin{aligned}
& \frac{\mathrm{P}_{\text {star }}}{\mathrm{P}_{\text {delta }}}=\frac{3 \times \mathrm{U}_{\mathrm{p}} \times \mathrm{I}_{\mathrm{p}} \times \operatorname{Cos}_{\varphi}}{3 \times \mathrm{U}_{\mathrm{p}} \times \mathrm{I}_{\mathrm{p}} \times \operatorname{Cos}_{\varphi}}=\frac{3 \times\left(\frac{380}{\sqrt{3}}\right) \times \mathrm{I}_{\mathrm{p}} \times \operatorname{Cos}_{\varphi}}{3 \times(220) \times \mathrm{I}_{\mathrm{p}} \times \operatorname{Cos}_{\varphi}}=\frac{3 \times\left(\frac{380}{\sqrt{3}}\right) \times\left(\frac{\mathrm{U}_{\mathrm{p}}}{\mathrm{Z}}\right) \times \operatorname{Cos}_{\varphi}}{3 \times(220) \times\left(\frac{\mathrm{U}_{\mathrm{p}}}{\mathrm{Z}}\right) \times \operatorname{Cos}_{\varphi}} \\
& \frac{\mathrm{P}_{\text {star }}}{\mathrm{P}_{\text {delta }}}=\frac{3 \times(220) \times\left(\frac{220}{\mathrm{Z}}\right) \times \operatorname{Cos}_{\varphi}}{3 \times(220) \times\left(\frac{220}{\mathrm{Z}}\right) \times \operatorname{Cos}_{\varphi}}=1
\end{aligned}
$$

\section{Simulations Results}

The MATLAB/Simulink block diagram related to the conducted simulation studies is given in Figure 8. While Figure 8a shows the simulation related to the star-connected
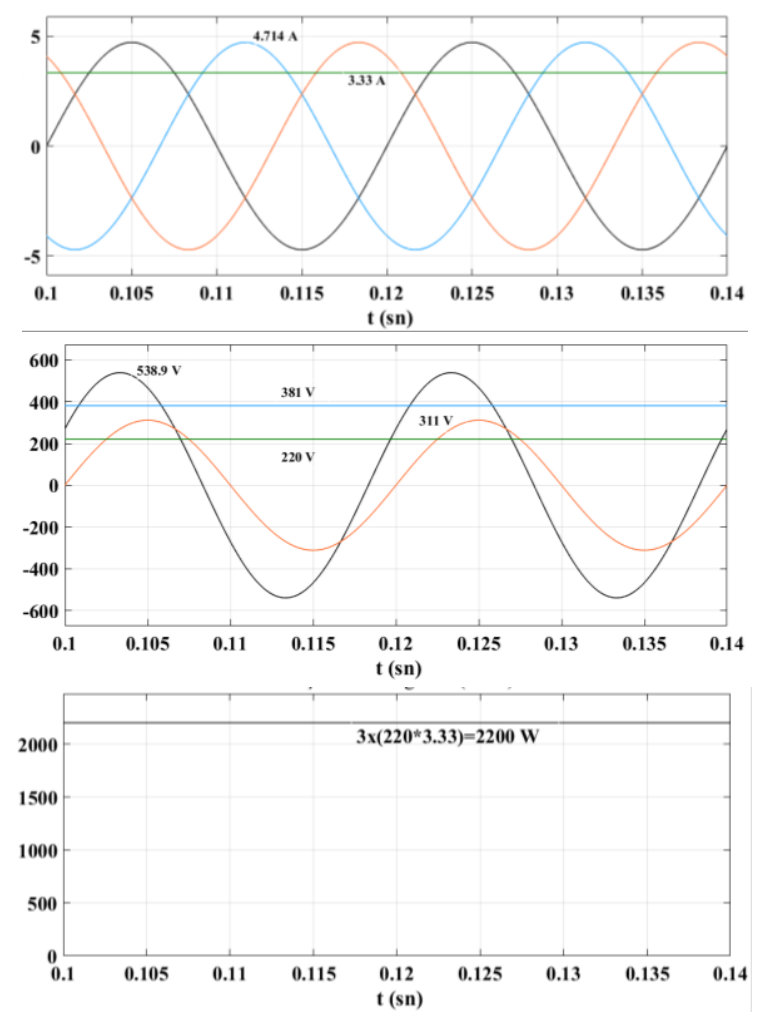

Figure 8a. Current, voltage and power graphs for star connections state of the load, Figure $8 \mathrm{~b}$ shows the delta-connected state of the load; also, the current, voltage, and power graphs obtained are given below.
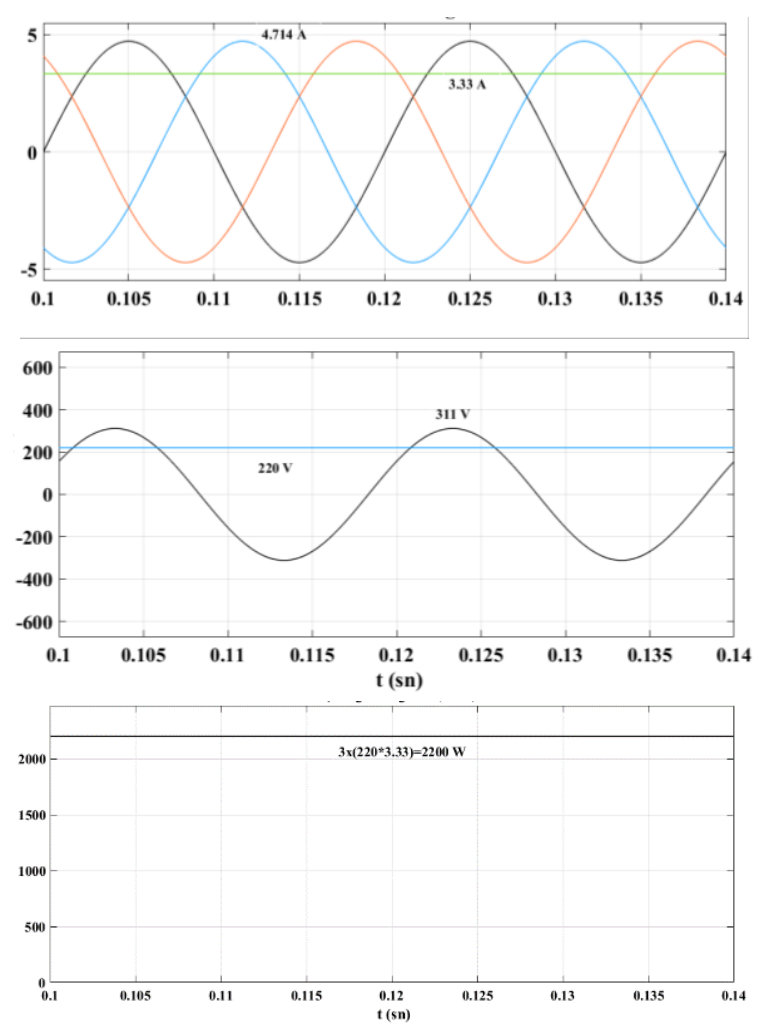

Figure 8b. Current, voltage and power graphs for delta connections 
In Figure 8a, the three phase source supplying the load was modeled as an AC source in which the effective value between the phases is $381 \mathrm{v}$ rms.

On the other side, in Figure $8 \mathrm{~b}$, the three phase source supplying the load was modeled as an AC source in which the effective value between the phases is $220 \mathrm{v}$ rms. The effective value of each phase current obtained as a result of the measurements from the three phase star-connected $\mathrm{R}$ load is $3.33 \mathrm{~A}$, the effective value of the voltage between phases is $381 \mathrm{v}$ and the effective value of the voltage of each phase winding is $220 \mathrm{v}$. On the other side, the power drawn from the source according to this phase current and voltages is obtained as $3 \times(220 \times 3.33)=2.2 \mathrm{~kW}$.

The effective value of each phase current obtained as a result of the measurements from the three phase delta-connected $R$ load is $3.33 \mathrm{~A}$, the current between the phases and the current of phase are equal and its effective value is $220 \mathrm{v}$. Similarly, the power drawn from the source according to this phase current and voltages is found as $3 \times(220 \times 3.33)=2.2 \mathrm{~kW}$.

Given the results obtained from simulations of the conditions for both the star and the delta connection, it is seen that in both cases, the power drawn by the load from the grid does not change. As a result, the asynchronous submersible motor, whose connection shape was transformed from $381 \mathrm{v}$ star to $220 \mathrm{v}$ delta, will continue to operate without any power change, power loss or performance degradation with the designed new photovoltaic irrigation system.

For the designed photovoltaic system, constructions to which 12 panels would be mounted were prepared and 6 panels mounted on a single leg by screwing to the stainless steel bases. The photos about the conducted mounting and field works are given in Figure 9.
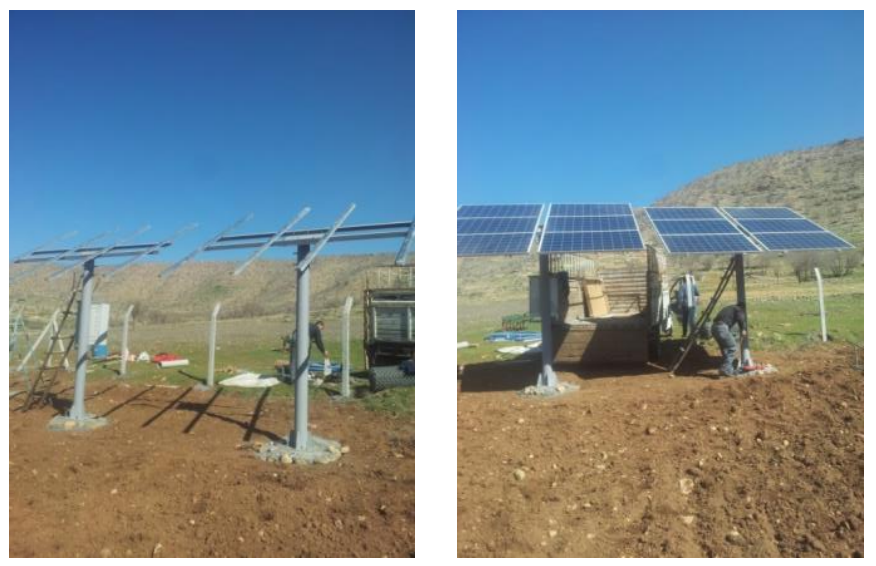

Figure 9. Installation of photovoltaic system in the field

Both the size and cost analyses of the designed system were performed and the obtained data are presented in Table VI below.
TABLE VI

SIZE AND COST ANALYSIS OF PHOTOVOLTAIC SYSTEM

\begin{tabular}{|l|c|c|}
\hline & $\begin{array}{c}\text { Motor } \\
\text { star connected }\end{array}$ & $\begin{array}{c}\text { Motor } \\
\text { delta connected }\end{array}$ \\
\hline Total Panel Number & 16 & 12 \\
\hline Total Panel Area & $26 \mathrm{~m}^{2}$ & $\approx 19.512 \mathrm{~m}^{2}$ \\
\hline Total Panel Cost & $2480 \$$ & $1860 \$$ \\
\hline Inverter Model & HSPL/H2200H & HSPL/H2200L \\
\hline Inverter Cost & $606 \$$ & $530 \$$ \\
\hline Construction Cost & $473 \$$ & $378 \$$ \\
\hline AC Cable Cost & $56 \$$ & $56 \$$ \\
\hline DC Cable Cost & $22 \$$ & $22 \$$ \\
\hline Connector & $75 \$$ & $75 \$$ \\
\hline $380 v$ Motor+Pump & $284 \$$ & $284 \$$ \\
\hline Wind. and Coil Cost & - & $13 \$$ \\
\hline Submer. Pump Hose & $56 \$$ & $56 \$$ \\
\hline Rope & $34 \$$ & $34 \$$ \\
\hline Cable Joint & $6 \$$ & $6 \$$ \\
\hline
\end{tabular}

\section{CONCLUSIONS AND RECOMMENDATIONS}

The design of the system is based on changing the winding of a 380v star-connected asynchronous submersible motor and converting its connection shape to $220 \mathrm{v}$ delta-connected as the fabrication. Through changing the winding of the $380 \mathrm{v}$ starconnected submersible motor and converting the connection shape of it to $220 \mathrm{v}$ delta, a decrease in the number of photovoltaic panels required for installed power was ensured. Due to the decrease in the number of panels, the physical area that the photovoltaic panels to be installed would cover was reduced, and a significant decrease in the total panel cost, inverter, construction, wiring, connector, labor and shipping costs was ensured. Such a system, which can be installed with smaller sizes and lower costs, is expected to be preferred by investors both in agricultural irrigation and in other areas.

\section{REFERENCES}

[1] Uluslararası Enerji Ajansı (IEA), "World Energy Outlook 2016", 2016.

[2] ABD Enerji Bilgi İdaresi (EIA), "International Energy Outlook 2016", Mayis 2016.

[3] EÜAŞ, "2016 Elektrik Üretim Sektör Raporu”, Mayıs 2017.

[4] Avrupa Komisyonu, "EU Energy in Fig., Statistical Pocket Book 2016", Belçika, 2016.

[5] Intergovernmental Panel on Climate Change, "Climate Change 2014, Mitigation of Climate Change", 2014

[6] US Environmental Protection Agency, "Global Greenhouse Gas Emissions Data", https://www.epa.gov/ghgemissions/global-greenhousegas-emiss.-data,29 Mayıs 2017.

[7] Boden T., Andres B., Marland G., "Fossil-Fuel CO2 Emissions by Nation", http://cdiac.ornl.gov/trends/emis/tre_coun.html\# , 29 Mayss 2017.

[8] Aksoy, M.H., "Güneş ve Rüzgar Enerjisi ile Çalışan Su Pompalama Sisteminin Deneysel İncelenmesi”, Selçuk Üniversitesi Fen Bilimleri Enstitüsü, Yüksek Lisans Tezi, 2011.

[9] Köksal, M.A.,,"Güneş Enerjisiyle su pompalama üzerine bir araştırma”, Çukurova Üniversitesi Fen Bilimleri Enstitüsü, Yüksek Lisans Tezi, 2012.

[10] Yeşilata, B. ve Aktacir, A., "Fotovoltaik Güç Sistemli Su Pompalarının Dizayn Esaslarının Araştııılması", Mühendis ve Makina Dergisi, 42 (493), 29-34, 2001. 
[11] Fiaschi, D.,et al,"Improving the effectiveness of solar pumping systems by using modular centrifugal pumps with variable rotational speed", Solar Energy, 234-244, 2005.

[12] Kavlak, İ. ve Güngör, H., "Fotovoltaik Piller ve Fotovoltaik Pillerin Tarımsal Sulamada Kullanılması”, I. Ulusal Güneş ve Hidrojen Enerjisi Kongresi, Eskişehir, 22-29, 2006.

[13] Purohit, B., and Kandpal, T., C., "Renewable energy technologies for irrigation water pumping in India: projected levels of dissemination, energy delivery and investment requirements using available diffusion models", Renewable \& Sustainable Energy Reviews, 592-607, 2005.

[14] Dursun, M. ve Saygın, A., "Güneş Enerjisi İle Çalışan Bir Sulama Sistemi İçin Boost Konvertörlü Anahtarlamalı Relüktans Motor Sürücüsü”, Erciyes Üniversitesi Fen Bilimleri Enstitüsü Dergisi, 22 (12), 57-65, 2006.

[15] Glasnovic, Z. and Margeta, J, "A model for optimal sizing of photovoltaic irrigation water pumping systems", Solar Energy, 81, 904 916, 2007.

[16] Ramos, J.S. and Ramos, H.M., "Solar powered pumps to supply water for rural or isolated zones: A case study. Energy Conversion and Manag.", 49, 2711-2719, 2008.

[17] Kaldellis J.K., et al., "Experimental validation of autonomous PV-based water pumping system optimum sizing", Renewable Energy, 34, 1106$1113,2009$.

[18] Granich, W. and Elmore, A.C., "An evaluation of the use of renewable energy to pump water in Sacala las Lomas, Guatemala", Environmental Earth Science, 61,4, 837-846, 2010.

[19] Dursun, E., vd., "Performance evaluation of a stand-alone photovoltaic/wind turbine/fuel cell power system for each province in the Aegean Region of Turkey", 5th International Ege Energy Symposium and Exhibition (IEESE-5), 298, 2010.

[20] Chen, H. H., et al., "Strategic selection of suitable projects for hybrid solar-wind power generation systems", Renewable and Sustainable Energy Reviews, 14, 413-421, 2010.

[21] Mokeddem, A., "Performance of a directly-coupled PV water pumping system", Energy Conversion and Management, 52, 3089-3095, 2011.

[22] Belgacem, B.G., "Performance of submersible PV water pumping systems in Tunisia", Energy for Sustainable Development, 16, 415-420, 2012.

[23] Yusufoğlu, G., "Şebeke elektriğinin bulunmadığı tarımsal alanlarda güneş enerjisiyle sulamanın yapılması", Marmara Üniversitesi, Fen Bilimleri Enstitüsü, Yüksek Lisans Tezi, 2013.

[24] Gençoğlu, E., "Güneş pili ile çalısan bir su pompalama sisteminin tasarımı ve gerçekleştirilmesi” Furat Üniversitesi Fen Bilimleri Enstitüsü Yüksek Lisans Tezi, Elazığ, 2015.

[25] Gündoğdu, A., "Fotovoltaik Sistemlerde Kısmi Gölgelenmenin Sistem Performansı Üzerindeki Etkileri”, International Engineering, Science and Education Conference, 54-64, 2016.

\section{BIOGRAPHIES}

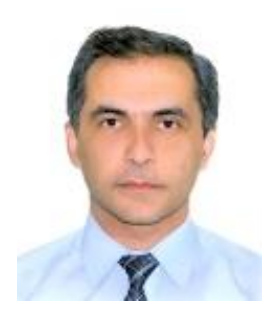

AHMET GÜNDOĞDU, Elazığ in 1974. He received the B.S. and M.S. degrees in electrical teaching from the University of Firat, Elazı ğ, in 2004 and the Ph.D. degree in electrical engineering from

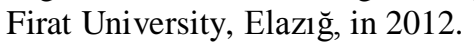

From 2000 to 2012, he was a Research Assistant with the electrical teaching department. Since 2013, he has been an Assistant Professor with the Electrical Engineering Department, Batman University. His research interests include magnetic levitation, electrical machines, motor control.

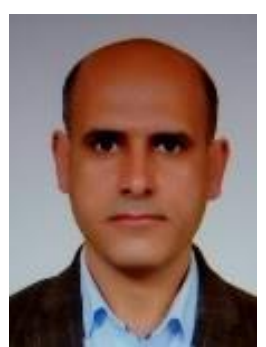

BAYRAM GÜRE Batman in 1974. He received the B.S. degrees in electrical teaching from the University of Dicle and M.S. degrees in renewable energy systems from the University of Batman, Batman, in 2018 . 